IRSTI 06.71.02

UDC 332.146 .2

\author{
L.I. KASHUK, ${ }^{1}$ \\ c.e.s., $\mathrm{PhD}$, professor. \\ Z.A. ARYNOVA, ${ }^{1}$ \\ c.e.s., professor. \\ S.V. BESPALY, ${ }^{1}$ \\ c.e.s, professor. \\ D.I. ZAKIROVA, ${ }^{2}$ \\ $\mathrm{PhD}$, professor. \\ Turan University ${ }^{2}$
}

Innovative University of Eurasia. ${ }^{1}$

\title{
TOOLS FOR A SYSTEMATIC APPROACH TO IMPLEMENTING CLUSTER INITIATIVES IN REAL SECTOR INDUSTRIES
}

\begin{abstract}
The main problem of the innovative development of the regions of Kazakhstan is the lack of innovative activity of enterprises, which is reflected in the volume, periodicity and impact of their innovations. At the same time, the majority of enterprises belonging to the real sector of the economy have sufficient resources for the development of innovative activities. However, the prospects for their interaction with enterprises in other sectors and sectors of the economy for technology transfer are insignificant. In this connection, the studies defining the main ways and methods of forming cluster initiatives in the regional economy are relevant. The analysis of the investment activity of industrial enterprises in the region predetermined the multidimensional nature of the research methodology, the need to use methods of system, statistical, comparative and logical analysis, grouping. The practical significance of the study is to develop specific recommendations to increase the investment attractiveness of Pavlodar region through the implementation of several cluster initiatives in the real sector. The results of the study allowed to develop some recommendations on the formation of a system for the implementation of cluster initiatives in the region, differing in their adaptation to the specifics of the industry, which made it possible to identify priority areas for the development of clusters in the real sector of the regional economy.
\end{abstract}

Key words: cluster, industry, system approach, real economy sector, region, priority areas, industry specifics.

Foreign and domestic experience shows that ensuring the technological competitiveness of real economy sectors is usually based on the implementation of cluster initiatives in their development. This makes it possible to increase the production indicators of companies, reduce their costs and those of service companies, and contributes to an increase in the innovative susceptibility of such sectors of the real sector as oil refining, petrochemical, mining and metallurgical, and agro-industry.

Clusters are complex system entities whose purpose in the economic system is to produce a specific list of tangible and intangible goods, which require a variety of resources to implement.

Modern socio-economic development is a multi-factor and multi-aspect phenomenon that needs to be studied from system analysis since emerging problems require system solutions. The relevance of the system approach is because only the system methodology and system methods of their resolution can be opposed to system crises [1].

The main features of the system approach are that it:

- focused on identifying all relationships and interactions in problems using logical, mathematical modelling, interdisciplinary and expert assessments;

- identifies goals and considers any system as a mechanism for achieving set goals;

- provides for the identification and preliminary playback of alternative options for achieving the goals and long-term prospects of each option;

- it is aimed at organic combination, coordination and integration of different types of activities both in the research process and in the implementation of its results.

In general, the activity of real economy sectors can be represented as the functioning of complex systems in a multidimensional space, which can only be described, predicted and optimized using 
a set of interrelated parameters. It requires scientific forecasting of trends and consequences of the development of large systems based on statistical and logical analysis of pervasive information [2].

For the effective functioning of real-sector industries, it is essential to create an interest in combining the efforts of enterprises in the extraction of raw materials, their processing and marketing in order to save on production costs and the basis of the introduction of new technologies. One of the forms of ensuring such mutual interest is the formation of vertically integrated companies in the form of joint-stock companies or partnerships with the connection of transport and petroleum supply enterprises.

For example, the petrochemical complex of the Pavlodar region belongs to complex and highly dynamic systems, which has a step-by-step nature of changing its elements and responsive to changes in target installations and external influences. The representation (decomposition) of socioeconomic systems can be performed on various grounds and, therefore, is ambiguous. Concerning the petrochemical complex, it is most appropriate to conduct it on three main grounds: management (level of management), territorial (zoning) and production and technological (nature of the technological process).

Let us take a closer look at the metallurgical cluster as one of the priority clusters of the Pavlodar region. In the region, the metallurgical cluster occupies a leading position: it accounts for the most significant part $(27.6 \%)$ of the total output of the region's industry. The metallurgical cluster of the region is represented by the production of ferrous metallurgy products: cast iron, steel, ferroalloys and the aluminium industry: bauxite mining and primary aluminium production. Pavlodar region is the only aluminium producer in the country.

The region's aluminium industry is represented by one company - "Aluminum of Kazakhstan" JSC, part of the national holding ERG. The company's annual output is 1.5 million tons of aluminium oxide (alumina) and 250 thousand tons of primary aluminium [3]. The cluster produces aluminium ingots, ingots, pipes, fittings, cast blanks, rolled balls, grinding and grinding, ferroalloys, and so on. However, the production of high-value products remains undeveloped, which is most

ly due to the lack of development or lack of supporting support services, logistics infrastructure, and other elements in the value chain. There are also difficulties with the availability of available raw materials: there is no iron ore Deposit in the region. Another type of raw material - scrap metal is available in small quantities, due to its active export to China, where its price is 500 us dollars per ton, and in Kazakhstan, it is sold at 300 us dollars per ton [4]. In the production of alumina and primary aluminium, bauxite is used from the Turgay and Krasnooktyabrsky deposits in the Kostanay region, owned by "Aluminum of Kazakhstan" JSC.

It should be noted that in the region there are many companies for the production of finished metal products, including Casting LLP-production of cast blanks, rebar, cast balls; PF LLP "KSR Steel" production of seamless steel pipes and rails; LLP "Pavlodar pipe rolling plant" - production of steel pipes; LLP "Technological lines" - production of moulded parts, stamps, etc. However, the aluminium industry in the region is still represented by low conversion rates: $67 \%$ of the produced alumina and $95 \%$ of primary aluminium are exported.

The second component of the metallurgical cluster of the Pavlodar region is the production of ferroalloys, represented in the region by TNK Kazchrom JSC - "Aksuferroslavov plant" JSC, whose operation is implemented against the background of active support under the SPFIID program and other measures of administrative support for the industry. As in the aluminium industry, the production of final products in the field of Ferroalloy production is almost at zero.

In addition to the raw material factor (the main one in metallurgical production), the cluster is also influenced by many other factors, such as the availability of markets, the level of infrastructure development, financial resources, administrative regulation, the level of enterprise development, etc.

In order to assess the strengths and weaknesses of the metallurgical cluster, a SWOT analysis is performed in table 1 (p. 51).

The results of the SWOT analysis and the content of the relevant documents that determine the development of the region in the future allow us to include the following among the main strategic directions for the development of the metallurgical cluster:

- the creation of a cluster Association;

- support for export development, export-oriented products; 
- development and production of alternative sources of raw materials for steel production;

- integration into international value chains;

- stimulating demand for metallurgical products. Development of a joint program with ERG for the sale of aluminium ingots in the region;

- researching the production of new types of metal-containing products (thermal packaging, explosives, etc.);

- initiating the extension of the law banning the export of scrap metal. Search for contracts for the supply of scrap metal from other regions of the Republic of Kazakhstan and the Russian Federation, etc.

Table 1 - SWOT analysis of the metallurgical cluster

\begin{tabular}{|c|c|}
\hline Strength & Weakness \\
\hline $\begin{array}{l}\text { - low cost of electricity; } \\
\text { - availability of its raw material base in the aluminium } \\
\text { industry within one holding ERG; } \\
\text { - equipment of ferrous metallurgy enterprises with } \\
\text { modern equipment and their modernization. }\end{array}$ & $\begin{array}{l}\text { - low-quality bauxite (raw material for the aluminium } \\
\text { cluster); } \\
\text { - high production cost; } \\
\text { - a high degree of wear of the leading equipment; } \\
\text { - undeveloped production of high-conversion products in } \\
\text { the aluminium industry. }\end{array}$ \\
\hline Opportunities & Threat \\
\hline $\begin{array}{l}\text { - the region has the potential to produce final products } \\
\text { (ferrous metallurgy, aluminium industry); } \\
\text { - emerging demand for cluster products in the domestic } \\
\text { market. }\end{array}$ & $\begin{array}{l}\text { - growth of scrap metal deficit in the region and the Republic; } \\
\text { - an increase in aluminium production and inventory in } \\
\text { China, stimulating a further fall in the price of aluminium; } \\
\text { - growth of tariffs of natural monopolies; } \\
\text { - the adverse reaction of the population to the opening of } \\
\text { new "harmful" industries. }\end{array}$ \\
\hline & \\
\hline
\end{tabular}

It should be noted that the high competitiveness of the Pavlodar region in the future until 2030, first of all, will be provided by the development of priority clusters, which include three main clusters in the region:

- metallurgical cluster, including the production of final products;

- railway engineering cluster;

- agri-food cluster.

As a result of the implementation of the strategy for the development of three priority clusters, more than ten new high-performance industrial sectors may appear or fully develop in the region (Table 2).

Table 2 - Clusters of Pavlodar region

\begin{tabular}{|l|l|l|}
\hline \multicolumn{2}{|c|}{ Clusters } \\
\hline \multicolumn{1}{|c|}{ Priority clusters } & \multicolumn{1}{|c|}{ Adjacent clusters } & \multicolumn{1}{c|}{ Potential clusters } \\
\hline $\begin{array}{l}\text { Metallurgical cluster, } \\
\text { including the production of } \\
\text { final products; } \\
\text { Cluster of railway } \\
\text { engineering; }\end{array}$ & $\begin{array}{l}\text { The cluster of chemicals and petrochemicals } \\
\text { The cluster of road and construction } \\
\text { Agri-food cluster }\end{array}$ & $\begin{array}{l}\text { Cluster } \\
\text { equipment } \\
\text { Transpourt and logistics cluster; } \\
\text { friendly recycling } \\
\text { A cluster of new energy } \\
\text { The cluster of innovative medicine } \\
\text { The cluster of modern production } \\
\text { technologies and engineering } \\
\text { Cluster for manufacturing components for } \\
\text { machinery and equipment } \\
\text { The cluster of industrial electrical and power } \\
\text { engineering equipment. }\end{array}$ \\
\hline
\end{tabular}

Success in the development of priority clusters in the future will create the demand and conditions for the formation of adjacent clusters of "tomorrow", which include the following: cluster chemistry, the cluster of road and construction machinery, transport logistics cluster, the cluster of innovative 
technologies and engineering cluster, the production of components for machinery and equipment, the cluster of industrial electrical and energy equipment. Clusters of the "future day", such as the cluster of resource efficiency and eco-friendly processing, the cluster of new energy, the cluster of innovative medicine, and the tourist and recreational cluster [6], can also potentially be born.

Regional cluster policy in the scientific environment is considered as an essential direction of regional industrial policy, and among the main directions of its development is indicated: maintaining and developing a competitive environment, maintaining and developing small businesses, developing an innovative production structure, supporting and developing the scientific and educational environment, identifying elements of cluster potential and developing cluster initiatives, creating mechanisms for interaction between the participants of the emerging cluster, stimulating the development of clusters, etc.monitoringtheinteractions [1].

If we evaluate the effectiveness of the cluster as an institution of regional development, the following fact is undeniable:

- the effectiveness of cluster functioning as a network form of business development in the region, including from the positions of individual economic entities, is practically reduced to zero. As already noted, the primary enterprises of this cluster are export-oriented and have practically no technological connections with the economic entities of the region;

- the performance of the cluster as the Institute of regional development, including its spatial development: primary metallurgical enterprises in the cluster towns, the role a sizeable regional labour market, creation and support of innovative infrastructure and development of the export potential of the region;

- cluster development is mainly carried out horizontally (acquisition of ownership by the base enterprise of production units that are a separate stage of the technological chain of production of the base enterprise). There is no vertical technological chain that is wholly or partially represented by processing: production - processing - production of final products in the region.

Modern approaches to managing and evaluating the effectiveness of cluster initiatives in a particular region do not always take into account the need to comply with the parameters of balanced development of territories, which traditionally include an assessment of the level of its socio-economic development, industrial, investment and innovation potential, and many others. Also, the present system of regional management to monitor the initiation and implementation of cluster initiatives are not given due attention because of methodological imperfections of existing analytical and diagnostic approaches and tools, and lack of awareness of the need for its implementation, which is mostly dictated by dysfunctional phenomena in the institutional control loop the process of spatial-economic goal setting [7].

\section{LIST OF LITERATURE}

1 Tatarkin A.I., Lavrikova Yu.G. Cluster policy of the region // Industrial policy in the Russian Federation. 2008. No. 8. P. 11-19.

2 Lavrikova Yu.G. Clusters: strategy of formation and development in the economic space of the region. Yekaterinburg: Russian Academy of Sciences, 2008. 271 p.

3 Zlivko A.V. Creation of industrial clusters as a priority direction of economic modernization. Materials of the International scientific and practical conference "Modernization as an alternative to globalization: the potential of economic integration of the CIS countries". - Krasnodar, TSNTI, 2012. Volume 1. P. 119-126.

4 Resolution of the Akimat of Pavlodar region "On approval of the action plan for the creation of a Regional innovation system" No. 307/9 dated August 26, 2013. [Electronic resource]. - Available at: http:// innovations.pavlodar.gov.kz/docs/ postanakimatpavlodarobl26082013307-9.pdf.

5 Report on sustainable development for 2017, Eurasian Resources Group. [Electronic resource]. Available at: http://www.erg.kz.

6 Official website of ERGhttps: / / www. erg.kz/ru/content

7 Program of development of the territory of the Pavlodar region for 2016-2020. [Electronic resource]. Available at: http://econompavl.gov.kz/category/ 23337/sub/23338/page/1105/. 
Л.И. КАШУК, ${ }^{1}$ э.Ғ.К., $\mathrm{PhD}$, профессор.

3.А. АРЫНОВА, ${ }^{1}$

э.Ғ.К., профессор.

С.В. БЕСПАЛЫЙ,

э.Ғ.К., профессор.

Д.И. ЗАКИРОВА, 2

$\mathrm{PhD}$, профессор.

Инновациялық Еуразия Университеті. ${ }^{1}$

«Тұран» университеті ${ }^{2}$

\title{
НАҚТЫ СЕКТОР САЛАЛАРЫНДА КЛАСТЕРЛІК БАСТАМАНЫ ІСКЕ АСЫРУ КЕЗІНДЕГІ ЖҮЙЕЛІК ТӘСІЛ ҚҰРАЛДАРЫ
}

\begin{abstract}
Андатпа
Қазақстан өңірлерін инновациялық дамытудың басты проблемасы кәсіпорындардың инновациялық белсенділігінің жеткіліксіздігі болып табылады, бұл олар жүзеге асыратын жаңалықтардың көлемдерінде, мерзімділігінде және нәтижелігінде көрініс табады. Бұл ретте экономиканың нақты секторына жататын кәсіпорындардың басым бөлігі инновациялық қызметті дамыту үшін жеткілікті ресурстарға ие. Алайда, олардың технологиялар трансферті мақсатында экономиканың басқа секторлары мен салаларының кәсіпорындарымен өзара іс-қимылының перспективалары елеусіз. Осыған байланысты өңірлік экономикада кластерлік бастамаларды қалыптастырудың негізгі жолдары мен әдістерін айқындайтын зерттеулер өзекті болып табылады. Өңірдің өнеркәсіптік кәсіпорындарының инвестициялық белсенділігін талдау зерттеу әдістемесінің көп аспектілі сипатын, жүйелік, статистикалық, салыстырмалы және логикалық талдау, топтастыру әдістерін пайдалану қажеттілігін анықтады. Жүргізілген зерттеудің практикалық маңыздылығы нақты секторда бірқатар кластерлік бастамаларды іске асыру арқылы Павлодар облысының инвестициялық тартымдылығын арттыру бойынша нақты ұсынымдарды әзірлеу болып табылады. Зерттеу нәтижелері саланың ерекшелігіне бейімделумен ерекшеленетін аймақта кластерлік бастамаларды іске асыру жүйесін қалыптастыру бойынша бірқатар ұсыныстар әзірлеуге мүмкіндік берді, бұл өңірлік экономиканың нақты секторында кластерлерді дамытудың басым бағыттарын бөлуге мүмкіндік берді.
\end{abstract}

Тірек сөздер: кластер, өнеркәсіп, жүйелік көзқарас, экономиканың нақты секторы, аймақ, басым бағыттары, саланың ерекшелігі.

Л.И. КАШУК, к.э.н., $\mathrm{PhD}$, профессор.

3.А. АРЫНОВА, ${ }^{1}$

к.э.Н., профессор

С.В. БЕСПАЛЫЙ, ${ }^{1}$

к.э.Н., профессор.

Д.И. ЗАКИРОВА,

$\mathrm{PhD}$, профессор.

Инновационный Евразийский университет. ${ }^{1}$

Университет «Туран»

\section{ИНСТРУМЕНТЫ СИСТЕМНОГО ПОДХОДА \\ ПРИ РЕАЛИЗАЦИИ КЛАСТЕРНОЙ ИНИЦИАТИВЫ В ОТРАСЛЯХ РЕАЛЬНОГО СЕКТОРА}

\section{Аннотация}

Главной проблемой инновационного развития регионов Казахстана является недостаточная инновационная активность предприятий, что находит отражение в объемах, периодичности и результативности осуществляемых ими нововведений. При этом большая часть предприятий, относящаяся к реальному сектору экономики, обладает достаточными ресурсами для развития инновационной деятельности. Однако перспективы
\end{abstract}


их взаимодействия с предприятиями других секторов и отраслей экономики с целью трансфера технологий незначительны. В этой связи актуальными являются исследования, определяющие основные пути и методы формирования кластерных инициатив в региональной экономике. Анализ инвестиционной активности промышленных предприятий региона предопределил многоаспектный характер методологии исследования, необходимость использования методов системного, статистического, сравнительного и логического анализа, группировки. Практическая значимость проведенного исследования заключается в разработке конкретных рекомендаций по повышению инвестиционной привлекательности Павлодарской области посредством реализации ряда кластерных инициатив в реальном секторе. Результаты исследования позволили выработать ряд рекомендаций по формированию системы реализации кластерных инициатив в регионе, отличающихся адаптацией к специфике отрасли, что позволило выделить приоритетные направления развития кластеров в реальном секторе региональной экономики.

Ключевые слова: кластер, промышленность, системный подход, реальный сектор экономики, регион, приоритетные направления, специфика отрасли. 